\title{
報文星切張力に関する研 究”
}

\author{
（第 2 報）実 験 的考 察
}

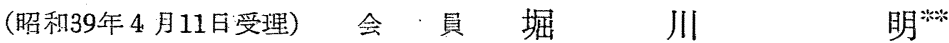

\begin{abstract}
$\longrightarrow$ 摘
摘

要

目的

牽切張力は牽切紡績における牽切の難易, 牽切機峨の設計, 牽切によって得たスライバの均せい度など, 牽切紡 績に関連した多くの情報を提供してくれることを第 1 報で理論的に知った。本報告ではさらに実験によって率切張 力現象を解明し，実際の荤切紡績への応用の可能性を示そうとする。

成果

牽切張力はドラフト比から 1 を引いた值に反比例し，ドラフト比が小さいと動力の増加，ミスカットの発生，な ど困難な事態が発生する。牽切張力の変動の形は牽切むらと相似の形になるので, 張力変動からむらを知ることが できる.
\end{abstract}

\section{1. ま えがき}

牽切紡績では, 引揃えた連続繊維の束を 2 組のローラ でつかんで引き切るので, そのローラによる完全なは持 すなわち適当な荷重が必要であり，また機台の構造も， その荷重ないしローラ間の張力に十分耐えるものでなけ ればならない。

すでに第 1 報で理論的考察を試みたのであるが，牽切 張力は紡出されるスライバの太さむらと同じものである ことがわかっている、このことは本報で実験的に゙確認 されるが，要するに率切張力現象を解明することは; 紡 出スライバのさらの解明と同じ意義を有するといらこと

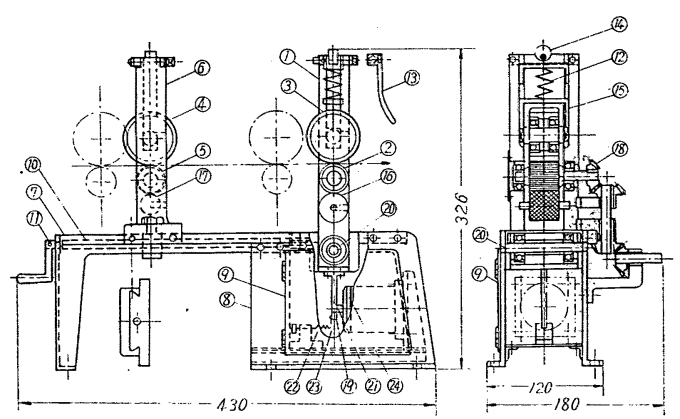

（第 1 脳）旁切張力測定装置
である.

牽切紡績，とくにパーロック式については，その理論 ならびに技術は主として日本で開発されてきたもので ある．紡績工程の簡略化，自動化がいわれてすでに久し い.ここ 2,3 年来リングトラベラ方式に対してさえ限 界が云々されている.

もら一度現在の技術的観点に立ってパーロック式を見 直してもいいのではなからうか.

\section{2. 斢切張力測定装置}

\section{1 牽切張力検出機構}

第 1 図のフロント ローラ部分を拡大して示すと第 2 図のようになる.白くニッケルめっきした部分 (3)がフロ ントローラ スタンドである，スタンド中央部に 3 本の ビスで止めた円板が見觉る。これはフロントボトムロ ーラ(2)のローラ ベアリングのカバーである。そん上に スタンドから少しはみ出して見える黒いのが, フロント トップローラ (1) である.スタンド下端は, ローラベ アリングにより軸 (20)で支党られている。この軸はフレ ームにナットで固定されている.

スタンド下端には, 連結棒 (19) が取付けられている.

* Draft-cut Force in Tow to Yarn System. Part 2: Experimentals. (第 1 報, 17巻, 8 号)

** A. Horikawa, Member. 大阪大学工学部 


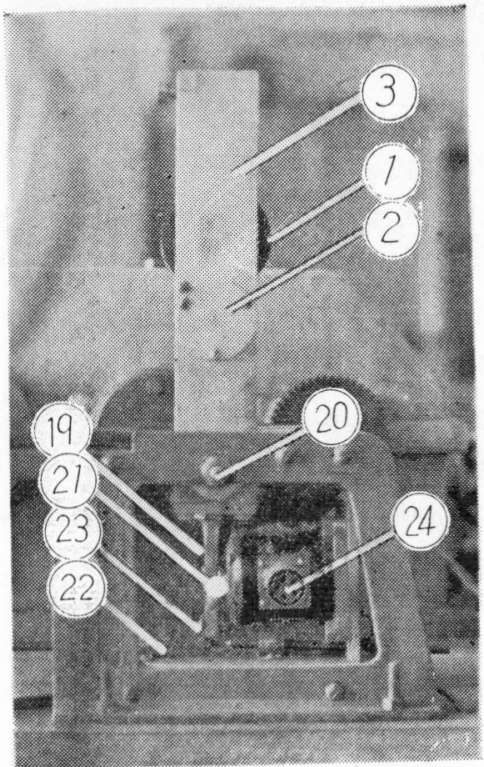

（第 2 図）毫切張力検出機構

率切張力が働らくとスタンドは図の左側に振れるが，軸 (20)で支壳られているので, 連結棒 (19) は右側に振れる. （振れの大ささは実際には $0.1 \mathrm{~mm}$ 以内である）連結棒 (19) はゴムクッションを経てストレーンゲージ式のロー ド セル (24) に牽切張力を伝える。連結棒下端には板ばね (23) があり，板ばねの下部はコイルばねで支兄れて， ダンパの役と0 点調整の役とを兼权ている.とくに (11) のゴム板はフロントローラを駆動するときに生ずる機 械的高調波を除くのに役立っている.

\section{2 フロントローラ駆動方式}

フロントローラの駆動には第 3 図の方式を採用する. 第 1 ベベルギヤ $B_{1}$ はフレームに支持され変速機から 駆動される、ベベルギヤ $B_{2}$ 以後のギヤはすべてロー ラ スランドに支持されている. ベベルギヤ $B_{1}$ とベベ ルギヤ $B_{2}$ との謎合いの位置は, スタンド支兑軸の中 心線に一致するよらにしてある. 外部からの動力は, べ ベルギヤ $B_{1}$ を経てベベルギャ $B_{2}$ に伝えられるが, ギヤ $B_{1}, B_{2}$ の㴹み合いの位置がスタンド支軸の中心線 上にあるので, 伝党られた力のスタンド支軸回りの回転 モーメントは 0 になる。 したがってこの歯車列によって ボトムローラに回転力は伝光られるが，スタンドを支 軸の回りに回転させようとする力はない、すなわちこの 機構によって率切張力に雑音を与兄ることなく, フロン トボトムローラを駆動することができ，ボトムローラ 駆動力に無関係にローラ スタンドの微小変位によって 率切張力を検出することができる。

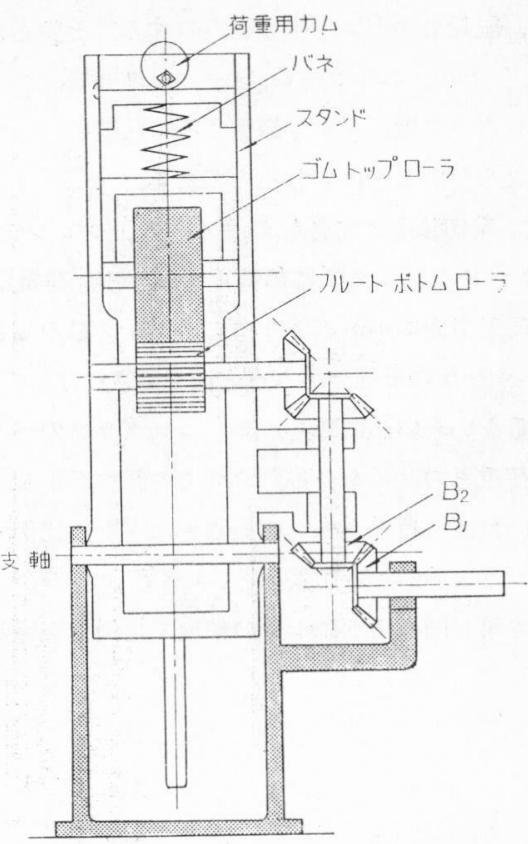

（第 3 図）フロントローラ駆動方式

\section{3 測定, 記録装置}

牽切装置の概略図と測定器類の結線図とは第 4,5 図 のようである。

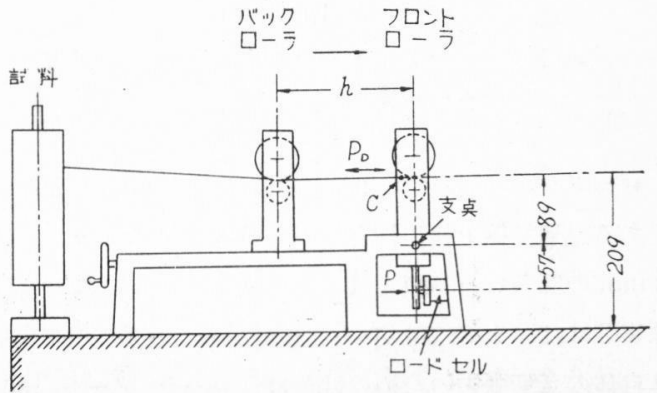

（第 4 図）毫切装置の概略

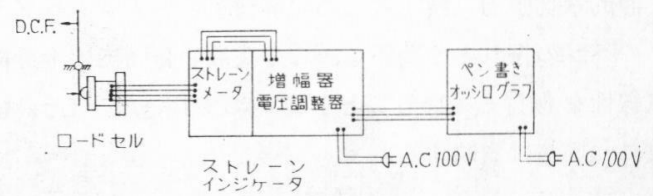

（第 5 図） 測定装置の配㯰

率切張力の大きさをあらかじめ検定するには，まず率 切装置を空運転し、スタンド下端の連結棒を圧している ゼロ点調整ばねを加減して,ロードセルに荷重がかから ないようにする。このときスタンドは直立, ロードセル と連結棒とはゴムダンパをかいしてわずかに接触を保 っている、ペン書きオッシログラフの針はこのとき振れ 
ないで，記録紙のゼロを指すようにする，そのときまで にロードセル, ストレーンメータ, 増幅器, ペン書き オッシログラフなどが十分調整ずみの状態になっていな ければならないことはもちろんである。

つぎに铉切装置は空運転のままとじ，フロントロー ラスタンドのフック $C$ に静荷重をかける。荷重は牽切 張力と同じ方向にかかるようにし，フックCの高さはフ ロソトローラの繊維つかみ点と同じ高さになっている.

静荷重をいろいろに変え, オッシログラフのペンの振 れと, 荷重との関係を見る。すべての調整が正しく行な われていれば, 荷重とペンの振れとは完全に比例する。

上のような静的な率切張力と,ロードセルのひずみと の関係は第 6 図のように十分の精度で比例している.

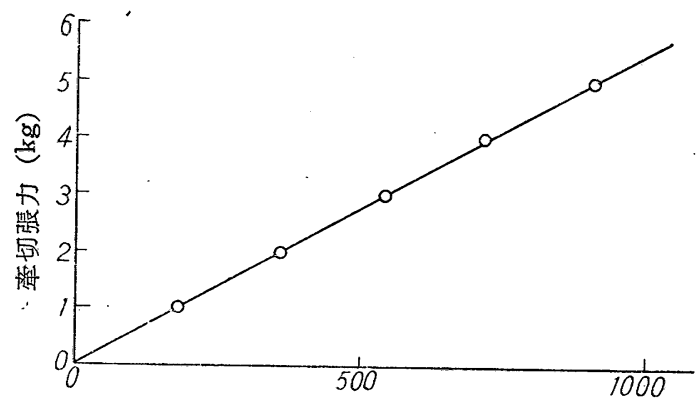
ひずみ $\left(\times 10^{-6} \mathrm{~mm}\right)$

（第6図）ロードセルのひずみと静的毫切張力 との比例性

ロードセルの荷重検出端の変位は $10^{-6} \mathrm{~mm}$ の大ささ である．連結棒と検出端との間には厚さ $1.5 \mathrm{~mm}$, 一辺 $8 \mathrm{~mm}$ の四角いゴム板をはさんであるが，連結棒の変位 は実際にはきわめて小さい。したがってフロントロー ラ自体の牽切張力のための変位は, ローラ ゲージ（80, $120,150 \mathrm{~mm})$ にくらべて無視できるほどに小さい.

静的率切張力（検定のための静荷重）とオッシログラ フのペンの振れとの関係も，この実験の䈟囲内で十分に 直線性を保持していることを確かめておいた。（その結 果については省略する)

\section{3. 試料の性質について}

ここではつぎの 2 種の試料を使用する。
$1.2 \times 4000 \mathrm{~d}$
ビスコース ブライトトウ
$1.5 \times 4.000 \mathrm{~d}$ ビスコースブライトトウ

牽切張力に関する理論的ならびに実験的考察を行なう ためには，単繊維の引張り特性を知る必要があるが，こ れらの值は, 試料長, 荷重方式, 荷重速度, 周囲の温湿
度によって数 $10 \%$ 差を生じ，とくに毫切のように繊 維束の状態で引張るときには, 束の各単繊維は単独のと きとは別の引張り挙動を示すので, 牽切張力を考察する ための単繊維試験法としては特別の注意が必要である. そこでこの項では単㵶維の引張り試験をいくらの試料長 で行なえば, 牽切張力の特性にもっとも適した資料が得 られるかいらことを実験的に考えてみよう。

牽切張力の考察に必要な単繊維引張り特性は

平均切断伸率： $\varepsilon_{c}(\%)$

平均切断強さ: $P(\mathrm{~g})$

単繊維が切断するまでの平均引張力: $P_{m} \cdot(\mathrm{g})$ の 3 つである.

（1）単繊維引張り特性と繊維束引張り特性

長さ $100 \mathrm{~mm}$ の繊維束 $(1.5 \times 4000 \mathrm{~d})$ を等速で引張 ったとさの荷重, 伸び曲線は第 7 図の細い実線のような 形になり，最大荷重に達するまでは，傾きの異なる 2 種 の直線からなり，頂点を過ぎると図のような曲線を画い て荷重ゼロに戻る。

単繊維の引張り特性はビスコースの場合, 繊維束の前 半分（頂点に達するまで）とまったく同じような傾きの 異なる 2 種の直線からなる特性を画き，その荷重が最大 に達したところで切断する。緎維束は頂点をもった山形 の分布をするが, 単繊維は頂点で切断してしまう。

繊維束は単繊維の集合であり，各単繊維間における伸 びの差や切断荷重の大きさの差が, 繊維束特有の特性曲 線を画かせているのである。したがって単繊維の特性か ら繊維束の特性を導出することがでさるはずである.

まず多くの単繊維引張試験の結果から（平均の荷重, 伸び曲線）を求める。 つぎに切断伸び率と，その（伸び 率に対する本数の累積頻度分布曲線）を求める。これら 両図から同一の伸び率に対する

(荷重 $) \times($ 本数の累積頻度 $) \times($ 束の中の繊維の本数 $)$ を求め, これをすべての伸び率について算出して図示す ると繊維束に対する荷重, 伸び曲線が求められる。

第 7 図の破線は, 繊維束と同じ試料長の $100 \mathrm{~mm}$ の単 繊維の（平均の荷重, 伸び曲線）と（伸び率に対する本 数の累積頻度分布曲線）とから計算によって求めた繊維 束の荷重, 伸び曲線である。繊維束とのものの引張り特 性と比皎すると，それよりも最大荷重が大きく，伸びは 小さくなっている.

つぎに単纎維試験の試料長を $10 \mathrm{~mm}$ として，上と同 様の実験と計算とを行ない, これから繊維束の荷重, 伸 び曲線を求めると図の太い実線（細線の中にかくれて見 


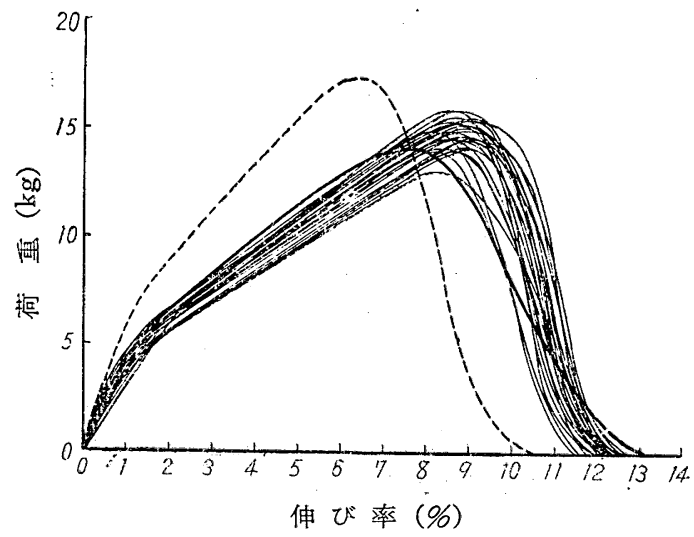

（第 7 図）単緎維の引張り特性から算出した㵶 維束の荷重, 伸び曲線己緘維束を直接 引張って得を荷重, 伸び曲線との比較

にくいが頂点以後はやや見やすい）のよらになり，繊維 束から直接測定した曲線（細い実線群）とかなりよく一 致するようになる。

以上のことから $100 \mathrm{~mm}$ 長さの繊維束の切断荷重や切 断伸び率を知るためには, $100 \mathrm{~mm}$ の単繊維試験の結果 から算出するよりも, $10 \mathrm{~mm}$ の単繊維試験の結果から 算出した方が，繊維束の実験結果とよく合らことがわか る.このように繊維束の長さより短かい単繊維について の資料から算出した方が実験とよく合うのはどらしてだ ろらか，つぎに簡単にその理由を考えてみよう。

繊維束の引張りにおいては, 各単繊維は, 横圧力を受 けて相互に伸びを制御し合い，各部が比較的均一に伸び ようとする傾向を生ずる。このような状態は繊維束自体 の長さよりも，はるかに短かい単繊維を引張ったときと 同じである。

同じ単繊維の引張り試験に和いても，100 mm のもの は.10 mm のすのにくらべて，1本の繊維の中に弱く伸 びの小さい点を含む確率が大きく、.. それだけ試験結果は 強度が小さく，伸びす小さくなりやすい。

（2）牽切張力考察の基礎資料として単繊維の引張り 特性から，㒕切張力を考察するときの基礎資料としての 単繊維の引張り特性を求めるには，制切に挑けるつかみ 長さよりずっと小さい試料長について試験した方がよい ことがわかる。

牽切に和いては;

荷重速度は…等速引張りと等速荷重引張りと両方の性 質があるが，だいたい等速引張りに近い

荷重をらける繊維長は…フロントローラ, バック口 ーラとすに回転しているので正しい意味

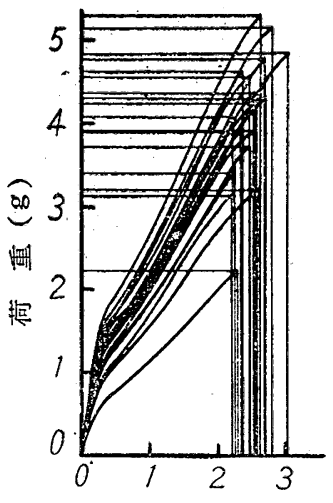

伸び (mm)

（第 8 図） $1.2 \mathrm{~d}$ 単緘維荷 重, 伸び特性

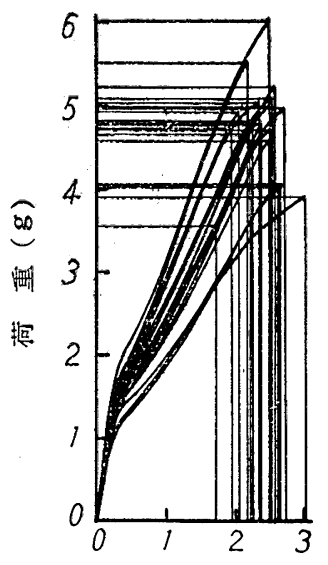

伸び (mm)

(第9 9図) $1.5 \mathrm{~d}$ 単繊維荷 重, 伸び特性
（第 1 表） 単緎維引張り特性值

\begin{tabular}{|c|c|c|c|c|}
\hline $\begin{array}{l}\text { 緎度 } \\
\text { (d) }\end{array}$ & $\begin{array}{c}\text { 平均切断 } \\
\text { 強 } \\
(\mathrm{g})\end{array}$ & $\begin{array}{c}\text { 平均切断 } \\
\text { 伸び率 } \\
(\%)\end{array}$ & \begin{tabular}{|c|} 
切断される \\
まざ張力 \\
の平均 \\
$(\mathbf{g})$
\end{tabular} & $\frac{(\text { 張力の平均) }}{\left(\begin{array}{cr}\text { 平均切断 } \\
\text { 強r }\end{array}\right)}$ \\
\hline 1.2 & 4.10 & 12 & 2.47 & 0.601 \\
\hline 1.5 & 4.77 & 12.06 & 2.87 & 0.602 \\
\hline
\end{tabular}

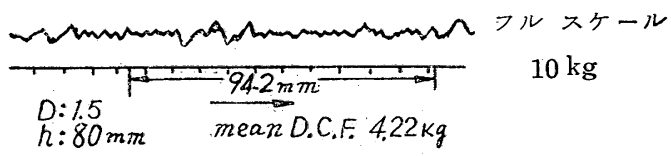

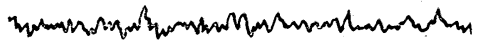

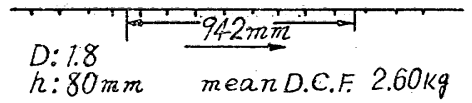

$5 \mathrm{~kg}$

$h: 80 \mathrm{~mm}$ meanD.C.F $2.60 \mathrm{~kg}$
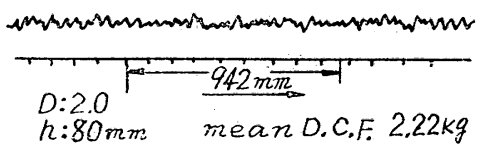

$5 \mathrm{~kg}$

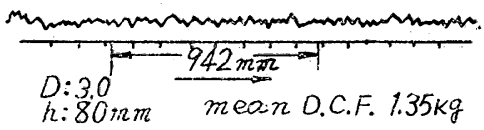

$5 \mathrm{~kg}$

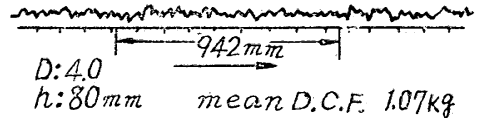

$5 \mathrm{~kg}$

$h: 80 \mathrm{~mm}$ mean D.C.F. $1.07 \mathrm{~kg}$

$2.5 \mathrm{~kg}$
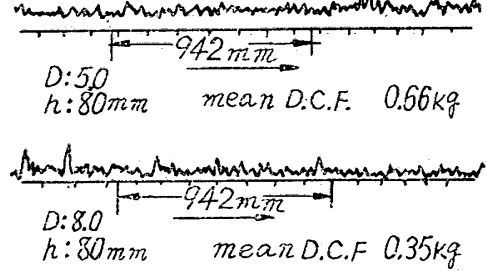

$2.5 \mathrm{~kg}$

（第 10 図） $1.2 \times 4000 \mathrm{~d}$ 
のつかみ長さは一定でないが，この場 合，近似的に最大繊維長を，その長さ と考えることとする。

切断伸び率は…1回だけ張力を受ける繊維もあるけれ ども 2 回以上張力を受ける繊維もあり 複雑であるが, 一応単㵶維試験の結果 から，その平均值をとることとする。

この実験においては

$$
\begin{aligned}
& \text { ドラフト 比: } D=1.5,1.8,2,3,4,5,8 \\
& \text { ローラ ゲージ: } h_{0}=80,120,150(\mathrm{~mm})
\end{aligned}
$$

最大繊維長: $l_{\max }=90 \sim 170(\mathrm{~mm})$

前の繊維束と単繊維との比較実験から考えて,このとき の単繊維試料長は $10 \sim 20 \mathrm{~mm}$ が適当である.ここでは $20 \mathrm{~mm}$ を試料長とする。

第 8,9 図は $1.2 \mathrm{~d}, 1.5 \mathrm{~d}$ のビスコース ブライト緎 維を試料長 $20 \mathrm{~mm}$, 標準状態 $\left(20^{\circ} \mathrm{C}, 60 \% \mathrm{R} \mathrm{H}\right)$ でテン シロン試験機（東洋測器株式会社製万能型繊維引張試験 機）にかけて引張ったときの資料である.

フルスケール
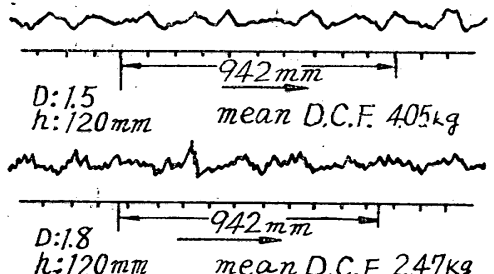

$h: 120 \mathrm{~mm}$ mean D.C.F. $2.47 \mathrm{~kg}$
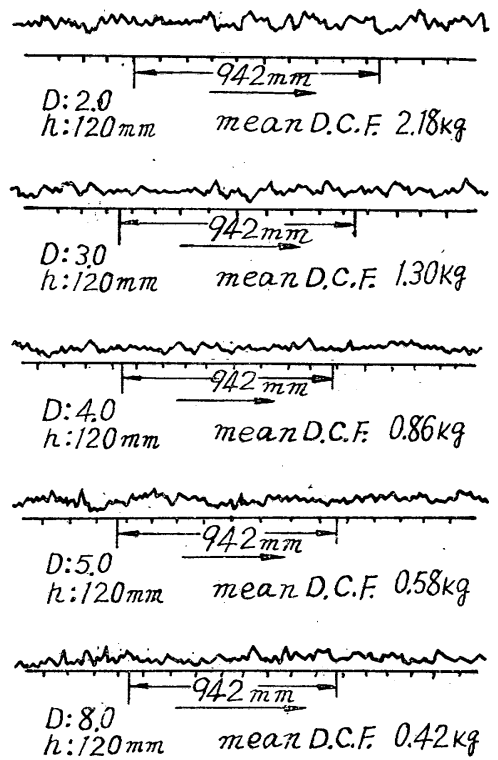

（第 11 図） $1.2 \times 4000 \mathrm{~d}$

$10 \mathrm{~kg}$

\section{$5 \mathrm{~kg}$}

$5 \mathrm{~kg}$

$5 \mathrm{~kg}$

$5 \mathrm{~kg}$

$2.5 \mathrm{~kg}$

$2.5 \mathrm{~kg}$
これから牽切張力の算出に必要な単繊維引張り特性を まとめると第 1 表のようになる。

単繊維が切断されるまでの張力の平均值は, 荷重, 伸 び曲線とよこ軸との間の面積をブラニメータで測定し, よこ軸の長さでその面積を割って算出した.

\section{4. 奉切張力曲線}

第 10〜12 図までは $1.2 \times 4.000 \mathrm{~d}$ について，第 $13 \sim 15$ 図までは $1.5 \times 4000 \mathrm{~d}$ にいての測定值で，上の方がド ラフト比 1.5 ,下の方へドラフト比が大きくなる.

ペン書きオッシログラフに拈けるペンの振れの大きさ

\begin{tabular}{|c|c|c|}
\hline $\begin{array}{c}\text { ドラフト比 } \\
(D)\end{array}$ & $\mid \begin{array}{c}\text { ペンの振机 } 1 \mathrm{~mm} \text { (記録 } \\
\text { 紙の } 1 \text { 目盛) } \\
\text { 張力 } \\
(\mathrm{kg})\end{array}$ & 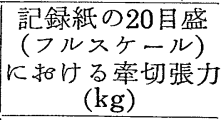 \\
\hline 1.5 & 0.5 & 10 \\
\hline $1.8,2,3,4$ & 0.25 & 5 \\
\hline 5,8 & 0.125 & 2.5 \\
\hline
\end{tabular}

（笠 2 表）ペンの振れの大きさと毫切張力の大きさ

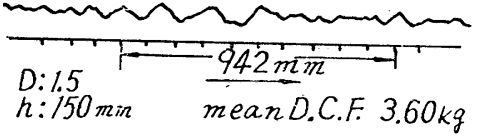

$10 \mathrm{~kg}$

$h: 150 \mathrm{~min}$ meanD.C.F. $3.60 \mathrm{~kg}$

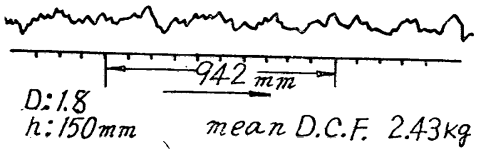

$5 \mathrm{~kg}$

h: $150 \mathrm{~mm}$, mean D.C.F. $2.43 \mathrm{~kg}$

$5 \mathrm{~kg}$
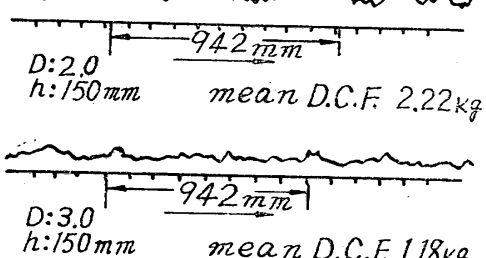

$5 \mathrm{~kg}$

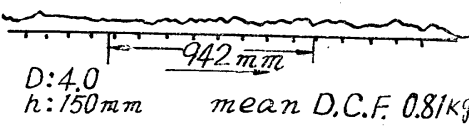

$5 \mathrm{~kg}$

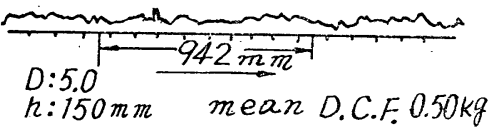

$2.5 \mathrm{~kg}$

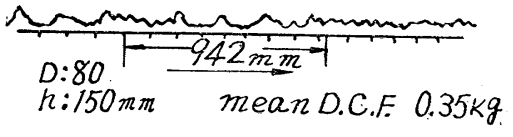

（第 12 困） $1.2 \times 4000 \mathrm{~d}$ 

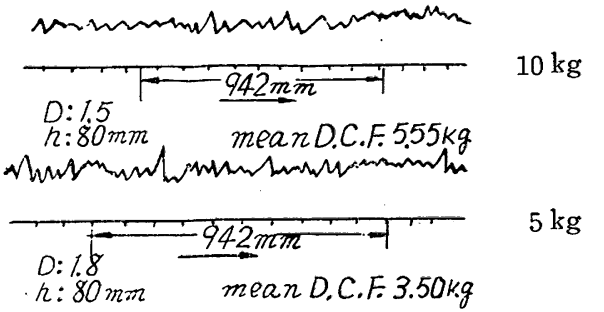

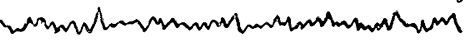
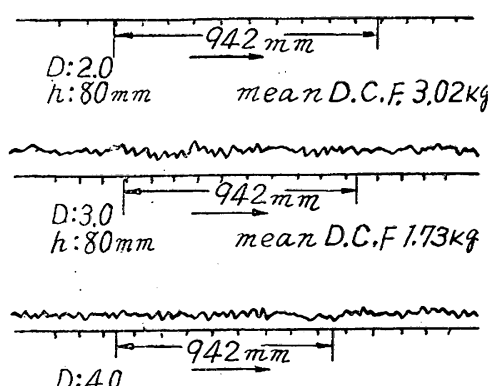

$h: 80 \mathrm{~mm} \quad$ mean D.C.F $1.15 \mathrm{~kg}$

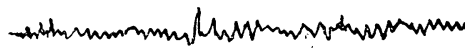

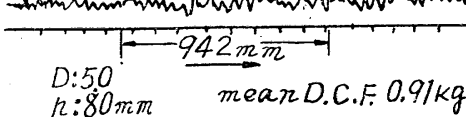

$n: 80 \mathrm{~mm}$

mean D.C.F $0.91 \mathrm{~kg}$

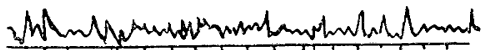

$D: 8.0$
$b: 80 \mathrm{~mm} \quad \frac{942 \mathrm{~mm}}{\operatorname{mean} D . C . F .} 0.55 \mathrm{~kg}$

$2.5 \mathrm{~kg}$

$5 \mathrm{~kg}$

$2.5 \mathrm{~kg}$

（第 13 図） $1.5 \times 4.000 \mathrm{~d}$

と牽切張力との関係は, ドラフト比の大きさによって第 2 表のように変えてあるが，いずれも振れの大きさと張 力の大きさとはすでにのべたと和り完全に比例する。

平均牽切張力は，一般にドラフト比が小さいときに大 きく，ドラフト比が増すにつれて急速に小さくなるが， ドラフト比が 5 を越すと、そその変化は小さくなる。この 傾向はローラゲージが変わっても，単織維の太さが変 わってむまったく同じである。

測定曲線の中で，長さ $942 \mathrm{~mm}$ を示してあるが，これ は（ボトムローラの直径） $\times \pi \times 10$ の值で，この長さ がボトムローラの10回転に相当することを示している。

$942 \mathrm{~mm}$ と書いた下の矢印は時間の進行方向（したが ってフロントローラからでてきたスライバの進行方向) を示し，図の左側から始まって右側で終わっていること を表わす。

張力ゼロの基線に短い線で区切ってあるのは，フロン トボトムローラの1回転ごとのタイムマークである.

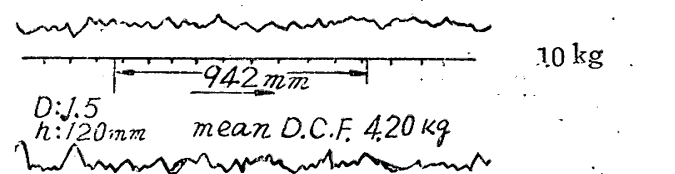

$5 \mathrm{~kg}$

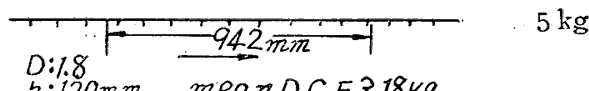

$\mathrm{h}: 120 \mathrm{~mm}$ mean D.C.F $3.18 \mathrm{~kg}$
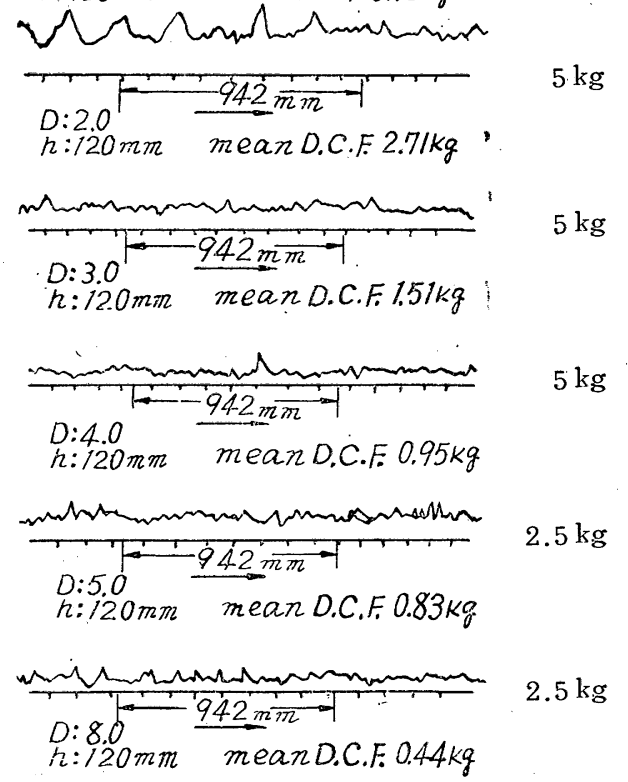

(第 14 図). $1.5 \times 4.000 \mathrm{~d}$

\section{5. 平均牽切張力}

オッシログラフで得た牽切張力の曲線と, 張力ゼロの 基準線との間の面積をブラニメータで測定し，長さで割 って平均牽切張力を出す.

第 16，17 図は平均牽切張力 $(\mathrm{kg})$ とドラフト比との 関係を示したもので, 理論結果が示すように, 平均害切 張力はドラフト比から 1 を引いた值：（D-1）が大き くなるにつれて双曲線的減少しているのがわかる。

理論式による平均率切張力は

$$
T_{\text {nean }}=n_{0} P_{m} \times \frac{2 \varepsilon_{\mathfrak{e}}}{(D-1)\left(1+\varepsilon_{e}\right)+D \varepsilon_{\mathfrak{e}}}
$$

これに第 1 表の值を入れて計算すると

$$
\begin{array}{ll}
1.2 \times 4.000 \mathrm{~d} \text { のとき } \quad T_{\text {mean }}=\frac{2.3}{1.1 D-1} \\
1.5 \times 4.000 \mathrm{~d} \text { のとき } \quad T_{\text {mean }}=\frac{2.5}{1.1 D-1}
\end{array}
$$

で表わされる. $D=2 \sim 8$ の範围で，上式をさらに書き かえると 

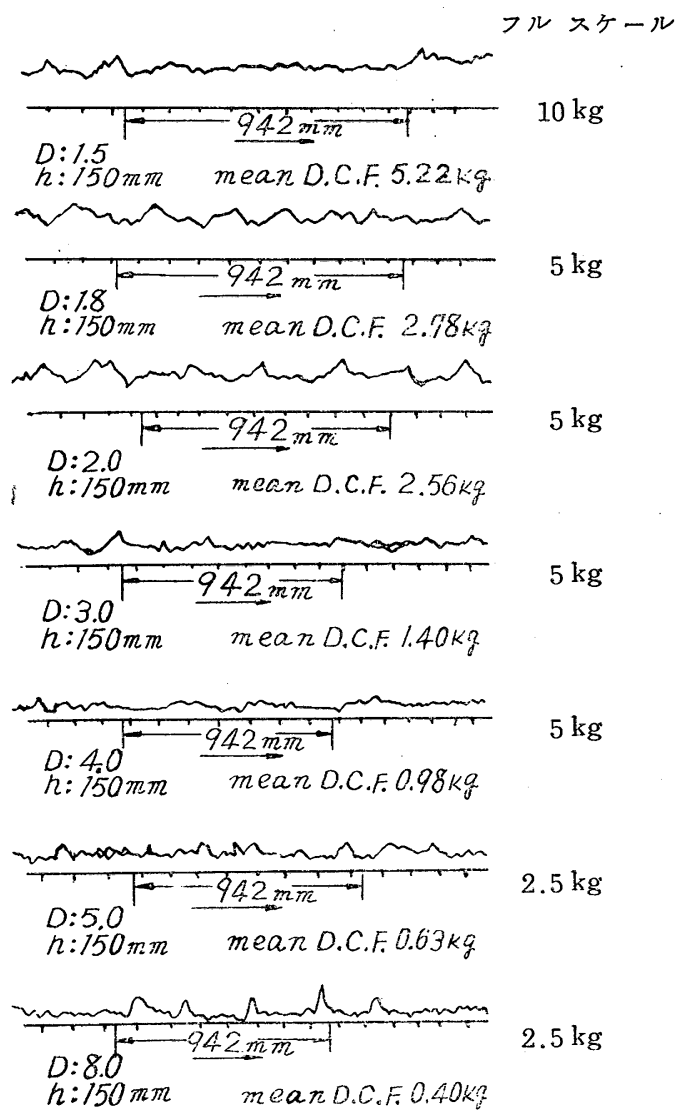

（第 15 図） $1.5 \times 4.000 \mathrm{~d}$

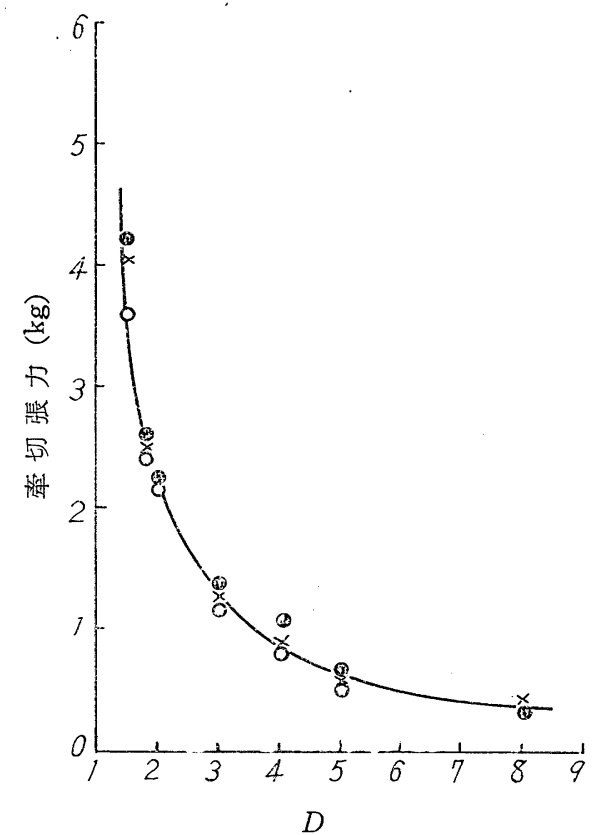

(3) $h=80 \mathrm{~mm} \times h=120 \mathrm{~mm} \bigcirc h=150 \mathrm{~mm}$ （第 16 図） $1.2 \times 4000 \mathrm{~d}$ ビスコース平均毫切張力

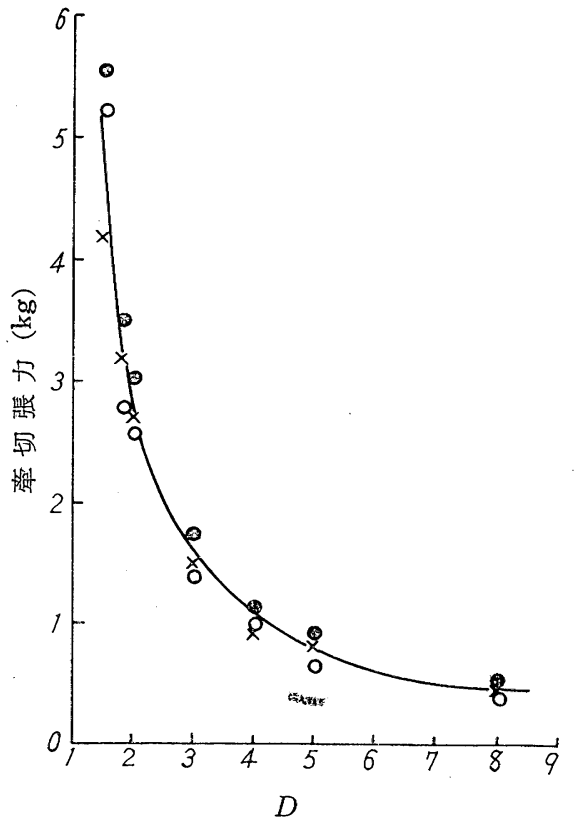

궁 $h=80 \mathrm{~mm} \times h=120 \mathrm{~mm} \bigcirc h=150 \mathrm{~mm}$ （第 17 図） $1.5 \times 4000 \mathrm{~d}$ ビスコース平均牽切張力
$1.2 \times 4.000 \mathrm{~d}$ のとき $T_{\text {mean }} \doteqdot \frac{2.1}{D-1}$
$1.5 \times 4.000 \mathrm{~d}$ のとき $T_{\text {mean }} \doteqdot \frac{2.3}{D-1}$

になる。一方実験結果による平均衰切張力を

$$
T_{\text {neanl }}=\frac{K}{D-1}
$$

で表わすこととし，Kの值を測定結果から求めると第 3 表のようになる。この表には理論値も示してあるが，こ の種の実験でこの程度ならば理論と実験とは十分あって いるといえよう。

（第 3 表） 平均旁切張力の実験式と理論式の比較

\begin{tabular}{|c|c|c|}
\hline 平均牽切張力 (kg) & $1.2 \times 4.000 \mathrm{~d}$ & $1.5 \times 4.000 \mathrm{~d}$ \\
\hline $\begin{array}{l}\text { 理論式: } n_{0} P_{m} \times \\
\frac{2 \varepsilon_{c}}{(D-1)\left(1+\varepsilon_{c}\right)+D \varepsilon_{c}} \doteqdot\end{array}$ & $2.1 /(D-1)$ & $2.3 /(D-1)$ \\
\hline 実験式: $\frac{K}{D-1}=$ & $2.3 /(D-1)$ & $2.7 /(D-1)$ \\
\hline
\end{tabular}

平均牽切張力がローラ ゲージの大きさとどのような 関係があるかを知るため，かりにドラフト比 $1.5 \sim 8.0$ の間の平均率切張力の和を取ることとし，これをローラ ゲージ別に整理すると第 18 図のようになる.

この結果から, 平均牽切張力がわずかであるが, ロ一 ラゲージの大ささと関係のあることがわかる，一般に 


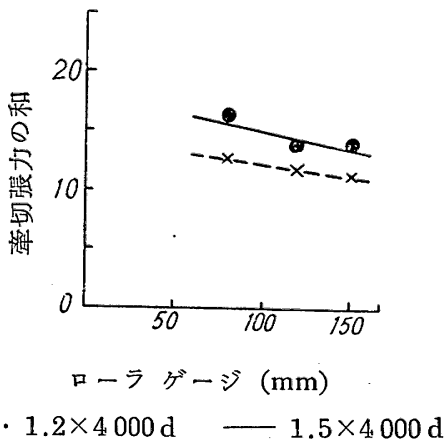

（第18 図）铑切張力とローラ ゲージとの関係

単繊維の引張り試験に和いては, 試料長が大きいほど引 張り強さが小さくなる傾向があるが，これと同じ理由で ローラゲージを大さくすると，各単繊維の引張り強さ が小さくなり，したがって平均牽切張力む小さくなると 考觉らる。

\section{6. 変動旁切張力}

牽切張力の測定曲線に颃いて, 曲線の 3 つ以上の頂点 に接する上限の張力を最大率切張力, 曲線の 3 つ以上の 谷に接する下限の張力を最小率切張力とする. 変動牽切 張力の周期長さの理論式は

$$
\left(l_{\max }+b_{\text {max }}\right)+\left(l_{\text {min }}+b_{\text {min }}\right)
$$

これは牽切むらの周期長さとまったく同じであるから， むらの周期長 $L_{p}$ をここでも牽切張力の周期長さの記号 とすると

$$
L_{p}=\left(l_{\max }+b_{\max }\right)+\left(l_{\min }+b_{\min }\right)
$$

$h_{n}$ を纎維のつかみ長さ（ローラゲージからトップロ 一ラ被覆ゴムの変形幅を差し引いた值）とすると

$$
\begin{aligned}
\frac{L_{p}}{h_{n}} & =\frac{(D-1)\left(1+\varepsilon_{c}\right)+D \varepsilon_{c}}{\left(1+\varepsilon_{c}\right)\left\{C-\left(1+\varepsilon_{c}\right)\right\}} \\
& +\frac{D \varepsilon_{c}+\left\{D\left(1+\varepsilon_{c}\right)-1\right\}}{\left(1+\varepsilon_{e}\right)}
\end{aligned}
$$

上の式を簡略化すると, $D=2 \sim 8$ の範囲で

$$
L_{p} \doteqdot h_{n} D
$$

が成立する。 この実験に括いては $D=1.5 \sim 8.0$

$$
h_{n}=(80 \sim 10) \sim(150-10)=70 \sim 140 \quad(\mathrm{~mm})
$$

したがって，理論周期長さは大約

$$
L_{p}=105 \sim 1120
$$

である.この実験で記録している変動牽切張力は, 衰切 スライバの長さで約 $2000(\mathrm{~mm})$ ，したがって，この間 には 3 ２0個の最大率切張力の「山」あるいは最小牽 切張力の「谷」が存在することになる、ここでは, 変動 衰切張力曲線の 3 つ以上の頂点に 接する上限の張力を
最大牽切張力とし，3つ以上の谷に接する下限の張力と した。

\section{1 牽切張力の変動幅}

最大牽切張力と最小毫切張力との差を牽切張力の変動 幅とする，第 10〜15 図の記録例でもわかるように，ド ラフト比が小さいときには平均牽切張力は大きく, その 変動幅も大さい、ドラフト比が大きくなると平均牽切張 力は小さくなるが；その変動幅も小さくなる．第 19,20 図は率切張力の変動幅を示している、変動の幅だけを見 るとドラフト比が大きいとき，変動幅は小さくなるよう

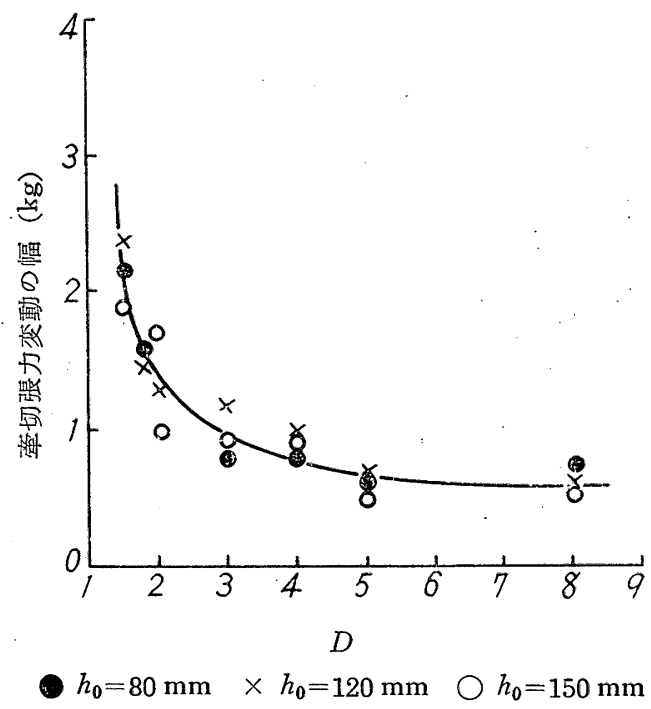

(第 19 図) 毫切張力の変動 (幅 $1.2 \times 4000 \mathrm{~d}$ ビスコース)

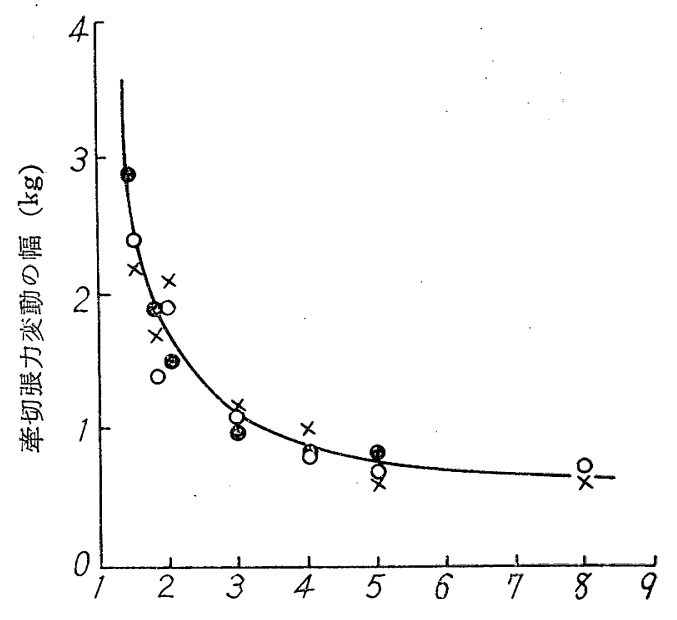

$D$

- $h_{0}=80 \mathrm{~mm} \times h_{0}=120 \mathrm{~mm} \bigcirc h_{0}=150 \mathrm{~mm}$ (第 20 図) - 毫切張力の变動幅 $(1.5 \times 4000 \mathrm{~d}$ ビスコース) 
に見えるが，スライバの太さがほぼドラフト比に反比例 して小さくなっているので, スライバの太さで割った值 (ここでは変動率と称している值) について考察する必 要がある，このことについては次項にのべる.

率切張力の変動幅は $1.2 \mathrm{~d}$ の方が $1.5 \mathrm{~d}$ よりわずかに 小さい.これは $1.2 \mathrm{~d}$ の方が $1.5 \mathrm{~d}$ より繊維の強さが 小さいためである。ローラ ゲージの影響については, ここで扱った 80〜150 $\mathrm{mm}$ の範囲では大差は認められな かった。

6.2 率切張力の変動率

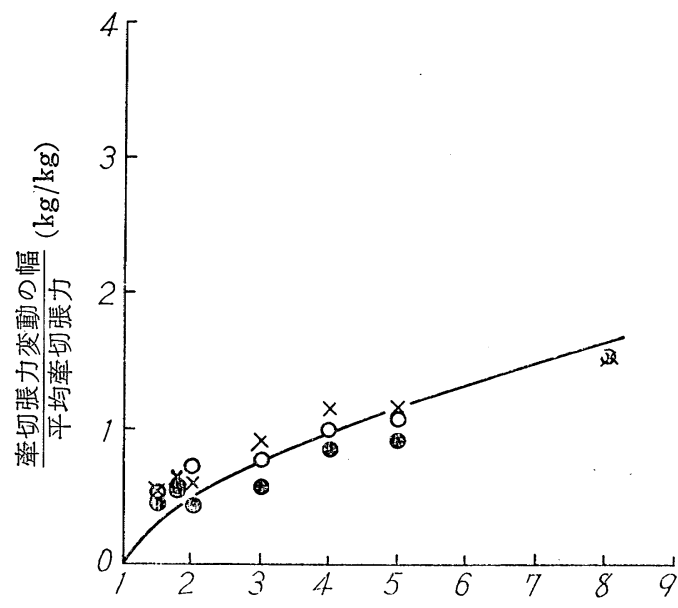

$D$

웅 $h_{0}=80 \mathrm{~mm} \times h_{0}=120 \mathrm{~mm} \bigcirc h_{0}=150 \mathrm{~mm}$ (第 21 図) 变切張力の変動率 $(1.2 \times 4.000 \mathrm{~d}$ ビスコース)

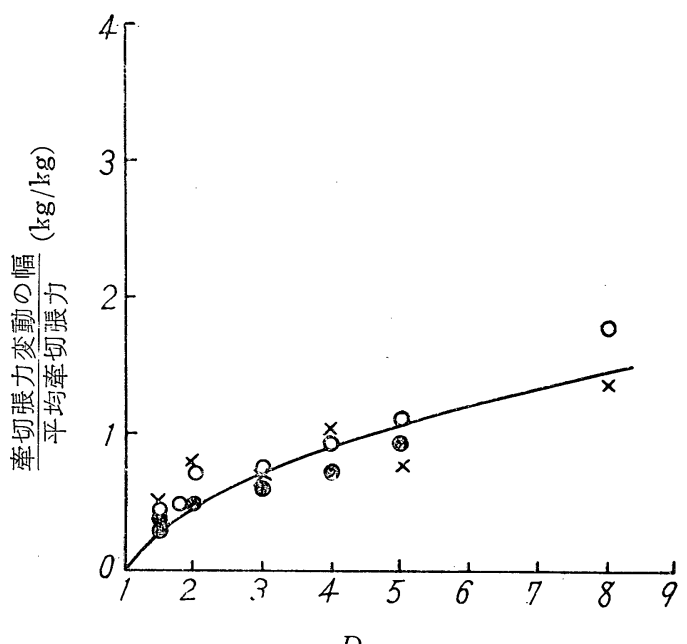

D

(2) $h_{0}=80 \mathrm{~mm} \times h_{0}=120 \mathrm{~mm} \bigcirc h_{0}=150 \mathrm{~mm}$

（第 22 図） 牽切張力の变動率 $(1.5 \times 4.000 \mathrm{~d}$ ビスコース)
牽切張力の最大値と最小值との差を平均牽切張力で割 った值を牽切張力の変動率とする。この変動率は変動幅 を平均值で割った值であるから，ドラフト比の異なる変 動率を比較してその大小を判定することができる。

第 21,22 図は牽切張力の変動率を示している. ドラ フト比が小さいとき変動率は小さいが，ドラフト比が大 きくなると変動率もしだいに増加する，この傾向は牽切 むらの傾向とまったく同じである，理論值もこれと同じ 傾向の曲線になるが，最大值と最小值との差は理論値の 方が実験值よりもはるかに大きい，

図の実線は理論値に定数を掛けた値を示している.

$1.2 \times 4.000 \mathrm{~d}$ のとき（理論值 $) \times 0.390=$ (実験值 $)$

$1.5 \times 4.000 \mathrm{~d}$ のとき（理論値 $) \times 0.334=($ 実験值 $)$ すなわち, 牽切張力の変動率に関する実験值は理論值の 約 $1 / 3$ で，ドラフト比を変えたときの牽切張力の変動率 の変化の傾向は理論値と同じである.

図の中でローラ ゲージが $80 \mathrm{~mm}$ の黒丸は，ローラ ゲージが $150 \mathrm{~mm}$ の白丸より一般に変動率が小さいよう に見える. 理論的に牽切張力の変動率は, ドラフト比 $D$ と繊維の切断伸び率 $\varepsilon_{e}$ との関数で表わされ, ドラフト 比Dが同一ならば繊維の切断伸び率 $\varepsilon_{e}$ の影響が入って くる.

単繊維の引張り試験においては, 試料のつかみ長さが 大さいほど切断伸び率は小さい。また理論的考察によれ ば切断伸び率の小さいものは, 牽切張力の変動率が大き い. したがってローラゲージが大きいと繊維のつかみ 長さが大さく，そのため切断伸び率が小さいので牽切張 力の変動率が大きくなる。

第 21,22 図はこれらの関係をも示しており，ローラ ゲージの小さい黒丸よりローラゲージの大きい白丸の 方が一般に変動率が大きくなっている.

\section{7. 牽切張力の変動率と牽切むらの変動率}

理論計算によると, 牽切張力の変動率と率切スライバ の断面繊維数の変動率とはまったく同じ関数で表わされ る。牽切域にある繊維を大別すると，すでに牽切ずみの 高速繊維群，バックローラにつかまれていてすでに制 切ずみの低速繊維群，フロント，バック両ローラにつか まれていて牽切過程中にある延伸織維群の 3 つになる. これらの繊維群の占める繊維数の割合の変化が牽切むら になり牽切張力の変動となって表われる。ところがこれ らの繊維群の占める纎維数の割合の変化は繊維切断点の 分布に起因している. 繊維切断点が分布すれば, 牽切む らや诨切張力の変動が表わ歽る゙，その機構はむらのと 


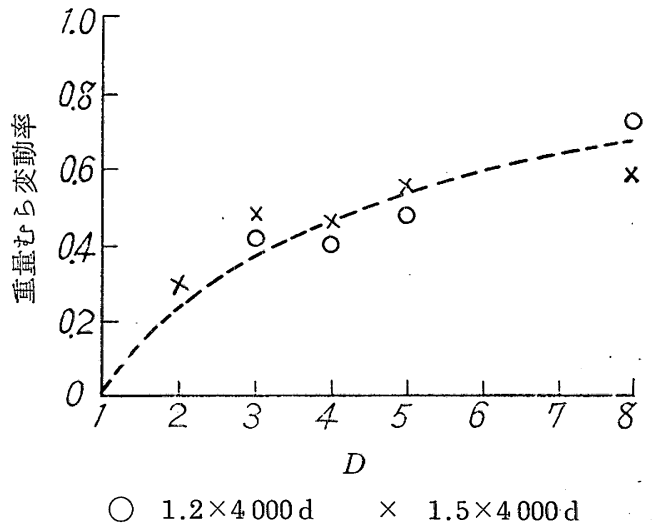

（第 23 図）牽切スラィバむらの变動率

きと張力のときとまったく同じで，理論的には

$$
\frac{T_{\text {max }}-T_{\text {min }}}{T_{\text {mean }}}=\frac{w_{\text {max }}-w_{\text {min }}}{w_{\text {mean }}}
$$

である。ここでいは牽切スライバの単位長 $(1 \mathrm{~cm})$ あ たりの重量 (mg) で, 上の式の值は牽切スライバの断面 繊維数の変動率に等しい.

第 23 図は牽切スライバさらの変動率である，第 21 , 22,23 図とのドラフト比に対する変化の傾向はまったく 同じであるが，その変動率の值は同じではない。この箺 験の場合

$$
\frac{T_{\max }-T_{\min }}{T_{\text {nean }}}=2.3 \frac{w_{\max }-w_{\min }}{w_{\text {niean }}}
$$

で, 牽切張力の変動率の方が, 牽切むらの変動率よりも 約 2 倍大きく表われている.

理論値は理想的な最大, 最小値についての変動率であ るが，実験ではそのような極端な值がでにくいことと， 測定上の誤差などが重なって理論值よりも小さな值にな ったと思わ机る。

\section{8. 牽切張力曲線と牽切むら曲線との比較}

牽切張力変動と牽切むらとは本質的に同じ原因（切断 点の分布, 変動) によって生じるので, 理論的には同じ 式で表現される。ところが前の実測結果が示すように， 率切張力の変動率, 率切むらの変割率は, それぞれ理論 值の約 $1 / 3,1 / 6$ に等しく, 前者は後者の約 2 倍の値にな る.しかしドラフト比の変化に対する傾向はまったく両 者とも理論傾向と一致する。

そこでさらに牽切張力曲線と牽切むら曲線とを同時に 記録し，それらの曲線を重ね合わせて直観的に比較して みよう。

実験では

$$
\text { ローラ ゲージ： } h_{0}=120(\mathrm{~mm})
$$

ドラフト比: $D=2,3,4,5,8$

試 料: $1.2 \times 4.000 \mathrm{~d}, 1.5 \times 4.000 \mathrm{~d}$ について行なった。

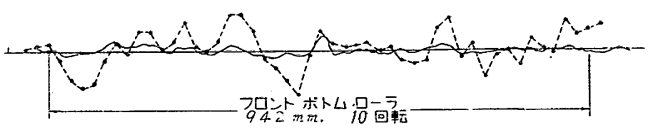

(1) $1.2 \times 4.000 \mathrm{~d}, D=2.0, h=120 \mathrm{~mm}$

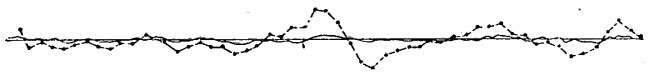

(2) $1.2 \times 4.000 \mathrm{~d}, D=3.0, h=120 \mathrm{~mm}$

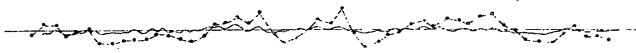

(3) $1.2 \times 4.000 \mathrm{~d}, D=4.0, \quad h=120 \mathrm{~mm}$

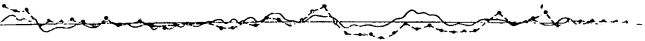

(4) $1.2 \times 4.000 \mathrm{~d}, D=5.0, h=120 \mathrm{~mm}$

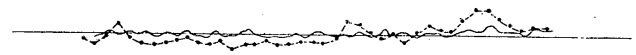

(5) $1.2 \times 4.000 \mathrm{~d}, D=8.0, \quad h=120 \mathrm{~mm}$ 実 線: 毫切張力の变動 破 線：覈切むら

(第 24 図)

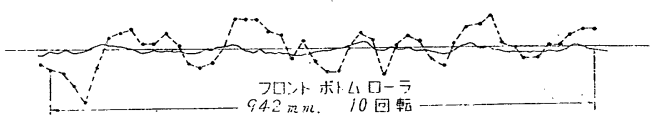

(1) $1.5 \times 4.000 \mathrm{~d}, D=2.0, \quad h=120 \mathrm{~mm}$

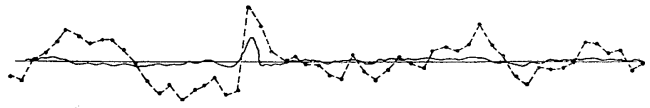

(2) $1.5 \times 4.000 \mathrm{~d}, D=3.0, h=120 \mathrm{~mm}$

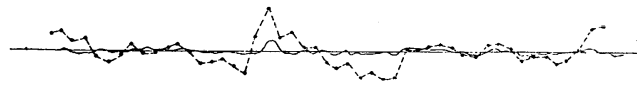

(3) $1.5 \times 4.000 \mathrm{~d}, D=4.0, h=120 \mathrm{~mm}$

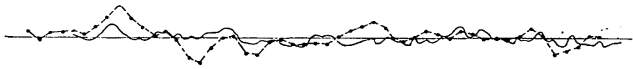

(4) $1.5 \times 4.000 \mathrm{~d}, D=5.0, h=120 \mathrm{~mm}$

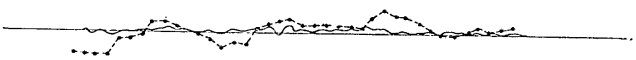

(5) $1.5 \times 4.000 \mathrm{~d}, D=8.0, h=120 \mathrm{~mm}$

実 線: 铑切張力の変動

破 線: 旁切む万

（第 25 図） 
牽切張力はペン書きオッシログラフで記録し，このと き同時に率切スライバに印を付けてフロントローラか らスライバを引き出し, 約 $1000 \mathrm{~mm}$ スライバが出たと き機械を停止，オッシログラフの記録を止める．スライ バを紙上に置き $20 \mathrm{~mm}$ ごとに切断計量して図示する. 一方ペン書きオッシログラフで得た曲線を写真に取り牽 切張力曲線の記録フイルムを引伸し機にそら入し, 率切 さら曲線と同率に拡大して両図を重ね合わせた。

第 24, 25 図はこうして得られた比較図である. 牽切 張力の測定において, ピックアップの感度は一定とし, 牽切むらと高さを揃えていない。平均值を示す線は一致 させてある. 平均值からの曲線の出, 入の状態, ふれ方 などを比べると，率切張力と牽切むらとがまったく等し い挙動をしていることがよくわかる.

ドラフト比が 5 のときは, 牽切張力のふれの高さと, 率切さらの変動の大きさとだいたい同じくらいの尺度に なっているので比較に便利である. 5 〜 $10 \mathrm{~mm}$ の小さな さらまで張力とさらとはよく一致している。

要するに，牽切張力の変動と牽切むらとは同じ形にな ることを実験的に知ることがでさた。

\section{9.むす び}

瀻維束を牽切するとき，バックローラとフロントロ 一ラとの間に作用する張力, すなわら率切張力は, 牽切 スライバのむらと相似の形状をもち, これによって牽切 中のむらを知ることができる。

平均牽切張力はドラフト比から 1 を引いた值 $(D-1)$ にほぼ反比例する。 ドラフト比が 2 以下のとさは率切張 力が大きいため, 大きな動力を必要とするばかりでなく
ローラのつかみ力もこれに伴なって大きくしなければな らない. ローラのつかみ力はローラ荷重の増加によって 大さくするが，これもまた牽切動力を大きくする原因で ある. ローラのつかみ力が牽切張力に対し適当でないと 繊維とローラの間にスリップが起こり,繊維束がミス カ ット（未牽切）され，これがさらに大きな張力を誘発す ることになり牽切そのものが困難になる.

変動牽切張力は谸切むらと相似の形になるので, 牽切 張力の変動曲線から率切さらの挙動を知ることができ る. 牽切張力の変動率はドラフト比の小さいとさは小さ く，ドラフト比 5 位までは急に，ドラフト比 5 以上では ゆるやかに増加する。この傾向は牽切さらの変動率と同 じである。

普通のさら測定機を使用した場合は，フロントロー ラから出てきたスライバを，そのむら発生源からある間 隔を置いたところで測定するため，むらの発生時刻との 間にかなりの時間差があった，ところが牽切張力と率切 さらとは同じ曲線の型になるので, 張力変動をむら曲線 の代用とし，張力変動からむらを検出することにすれば むらの発生源に执いて，その発生時刻にむらを検出する ことが可能になる。ぬた一般に張力変動の測定はむらの 測定よりも容易である.

なお,この研究は藤野先生の御鞭撻に負うところ多大 である。ここに記して謝意を表わします。

\section{文献}

1) 堀川: 毫切張力に関する研究 (第 1 報), 本誌, $17,8,9(1964-8)$

\section{敬 異 の LASER}

原子力についで発見された驚嘆のエネルギL A S ERとは何か.これは Light Amplification by Stimulated Emission of Radiation の頭文字を取 った新語である.すなわち「発光体の励起された放 射によって起こる光源の増幅」とでも訳すべきか.

その電磁波の誘導放出による光線の増幅エネルギ は太陽面エネルギの出力に対し同一面積で 1 億倍に 達し速力は大陸間弾道弾（I C BM）の時速 1 万 5 千マイルに対しLASERは秒速18万6千マイルと のことである.

L A S E Rはもはや制御不可能な狂暴性を有する 形態のエネルギではなく医学, に宇宙探険に, 工業
にあるいはまた軍備関係にまで役立つものとなり つつある.

L A S E R 光線は $1 / 4$ in鋼板を容易に打ち抜き，立 た精密照準や測定装置に応用されるようになった。 またいままではとうてい測定困難な超遠距離も測る ことができる。

L A S ERについては素人に解りやすいように書 かれた Rotarian 誌 6 月号の全訳および Machinery 1964年 4月15日発行にやや専門的に, 記述したもの の摘訳が当学会に備えつけてあるから與味ある方は 御一覧の上もし希望者多数なれば, 実費再版配布し てもよいと思っている.

(T.F.) 